\title{
Comparison Between Flapped and Flapless Implant Techniques by Measuring Crestal Bone Level: A Prospective Radiographical Trial
}

\author{
Ali J. Abdul-Saheb
}

B.D.S, H.D.D, M.Sc.- Lecturer, Department of Prosthodontics, College of Dentistry, University of Baghdad. Resha J. Abdul-Saheb

B.D.S, M.Sc. - Assistant Lecturer, Department of Oral diagnosis, College of Dentistry, University of Baghdad.

Abdalbasit A Fatihallah

B.D.S, M.Sc, Ph.D. - Assistant Professor, Department of Prosthodontics, College of Dentistry, University of Baghdad.

\begin{abstract}
Background: Previously, the flapped dental implant surgery was the most common implant placement procedure. With the development of different implantation techniques, the flapless surgery is now available for implant placement. The aim of this study was to evaluate the effect of the flapless surgical technique for implant placement on bone level compared with the flapped surgery technique with the aid of panoramic Resha J. Abdul-Saheb imaging.

Materials and methods: The study comprised 10 patients, 20 dental implants investigated, two implants placed for each patient (one implant placed with a flapped procedure and the other with a flapless surgical technique). Utilizing panoramic view pre- and post-surgical treatment, the crestal bone level at different intervals ( 1 week, 4 weeks and 12 week) has been compared.

Results: When comparing flapped and flapless implant surgical procedures at different time intervals, the flapless surgical technique showed less bone level reduction, on the other hand no significant results obtained when comparing the surgical techniques in the maxillary and mandibular arches.

Conclusion: Flapless implant placement provides less bone level reduction compared with the flapped technique.
\end{abstract}

\section{KEYWORDS:}

flapless surgical technique, crestal bone level, bone level loss

\section{CITE THIS ARTCLE:}

Abdul-Saheb A, Abdul-Saheb R, Fatihallah A. Comparison Between Flapped and Flapless Implant Techniques by Measuring Crestal Bone Level: A Prospective Radiographical Trial. Iraqi Dent. J. 2015; 37(2):51-55. http://www.iraqidentaljournal.com

$$
\begin{aligned}
& \text { مقارنة طريقتين جراحيتين لزراعة الاسنان من ناحية مستوى العظم المحيط بالزرعة بواسطة أشعة الوجه والفكين }
\end{aligned}
$$

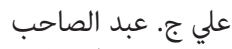

$$
\begin{aligned}
& \text { مدرس - قسم صناعة الأسنان - كلية طب الص الاسنان - جامعة بغداد } \\
& \text { رشا ج. عبد الصاحب الصنان } \\
& \text { مدرس مساعد ـ قسم التشخيص الفمي - كلية طب الاسنان - جامعة بغداد } \\
& \text { عبد الباسط احمد فتح الله } \\
& \text { استاذ مساعد ـ قسم صناعة الاسنان ـ كلبة طب الاسنان - جامعة بغداد }
\end{aligned}
$$

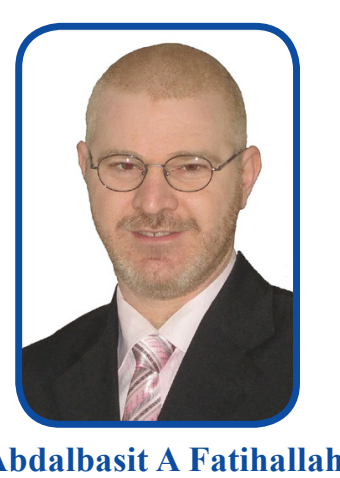

Abdalbasit A Fatihallah

Ali J. Abdul-Saheb

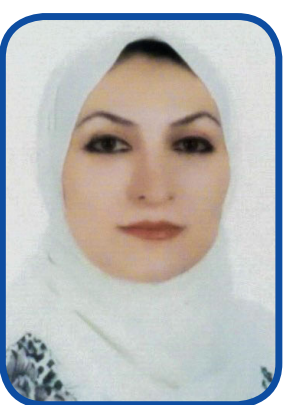


comfort, soft tissue circulation and architecture ${ }^{8}$, and it has been widely used in recent years ${ }^{9}$.

To ensure less trauma during surgical placements of dental implants, and less surgical time, a flapless technique can be used with the aid of a surgical stent but it requires a good bone quality ${ }^{10}$. It is regarded as a blind procedure and the operator cannot evaluate the alveolar bone quality ${ }^{4}$; therefore, it needs an advanced clinical experience and surgical judgment $8,11,12$.

The disadvantages of the flapless surgical technique include inability to visualize anatomical landmarks, thermal damage due to reduction of coolant irrigation during preparing the socket, and mal-posed angle of dental implants ${ }^{8,11,12}$. The advantages of the flapped surgical procedure are: it provides good access to the implant site, allows good visualization to anatomical landmarks, and allows bone graft placement, when required ${ }^{8,11,12}$.

For initial healing and osseointegration, a healing phase from three to six months is required; however, another idea supported by recent research, says that directly loading implants following fixture placement provides equal levels of osseointegration; moreover, it may stimulate osseointegration and resist osteolysis 13,14 .
This study was designed to evaluate the amount of crestal bone loss level between using the flapped and flapless dental implant surgical procedures at different time intervals.

\section{MATERIALS AND METHODS}

Ten patients aged $4-45$ with good oral hygiene and no previous medical problems were selected and they underwent full arch treatment. The size of the implants ranged from 3.8 to $4.2 \mathrm{~mm}$ according to the bone width and the length was from 10 to 12 $\mathrm{mm}$ according to the bone height. Dentium implants (Dentium Company, Korea) were used. The level of crestal bone around the dental implants were measured using iron panoramic image. Twenty implants were investigated; ten implants were inserted by the flapped technique surgery and ten by the flapless technique.

The implants were placed in the $1^{\text {st }}$ premolar and $1^{\text {st }}$ molar areas in both jaws, due to the preferable width of the bone (in anterior area knife-edge bone founded in most of cases so that it was excluded).

The bone level was measured by using Autodesk AutoCAD 2014 program; a line was drawn from the top surface of the implant to the point of implant fixture's surface contact with the bone. The line was parallel to the long axis of the implant and perpendicular to the alveolar bone as shown in Fig. 1.

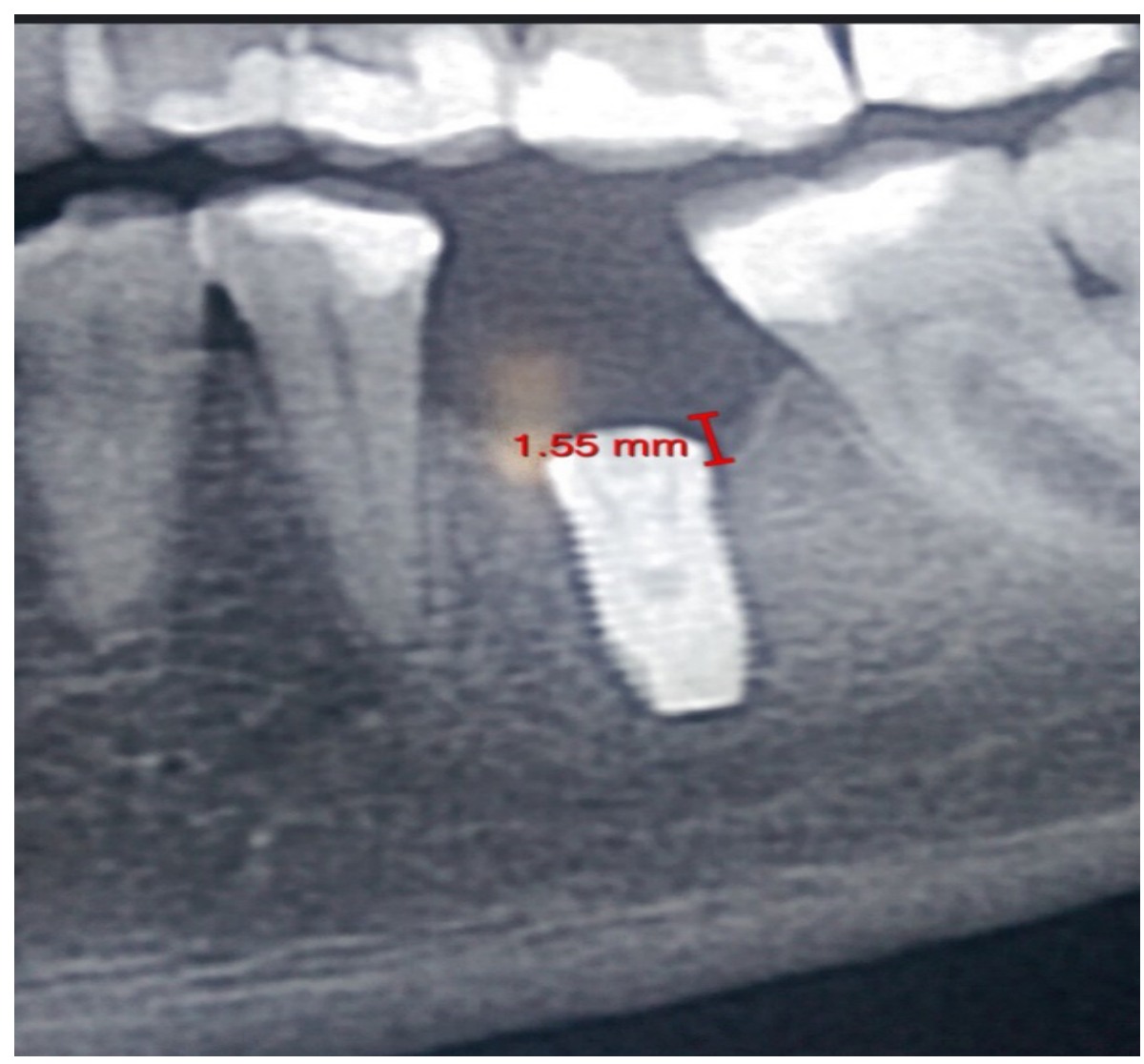

Fig. 1. Measurement of bone level at the area of $1^{\text {st }}$ molar after 1 week of implant insertion

The crestal bone level was measured at 1,4 , and

12 weekly intervals after implant insertion, and a comparative analysis was made between the flapped and flapless techniques by using two-independent 
variable statistical analysis.

\section{RESULTS}

Table 1 shows descriptive statistics for the crestal bone level measurements at different time intervals. The crestal bone level mean of the flapped surgery technique at first week after surgery was $1.28 \mathrm{~mm}$ with $\mathrm{SD} \pm 0.25$, after 4 weeks it was $2.75 \mathrm{~mm}$ with $\mathrm{SD} \pm 0.53$, and after 12 weeks, it was $1.85 \mathrm{~mm}$ with $\mathrm{SD} \pm 0.27$.

The mean of the crestal bone level of the flapless surgery technique at first week after surgery was 1.35 $\mathrm{mm}$ with SD \pm 0.21 , after 4 weeks, it was $1.80 \mathrm{~mm}$ with $\mathrm{SD} \pm 0.28$, and after 12 weeks, it was $1.03 \mathrm{~mm}$ with $\mathrm{SD} \pm 0.08$.

The measurement of the crestal bone level of the flapless technique at first week was $1.38 \mathrm{~mm}$ with $\mathrm{SD} \pm 0.19$ in the maxilla, and 1.25 with $\mathrm{SD} \pm 0.35$ in the mandible, while after 4 weeks it was $1.84 \mathrm{~mm}$ with $\mathrm{SD} \pm 0.23$ in the maxilla, and 1.63 with $\mathrm{SD} \pm 0.53$
As compared between the flapped and flapless technique, the P-value at the first week was nonsignificant, after 4 and 12 weeks it was highly significant, as shown in Table 2 .

The results of the comparison between maxilla and mandible in both techniques are shown in Table 3.The measurement of the crestal bone level of the flapped technique at first week was $1.28 \mathrm{~mm}$ with $\mathrm{SD} \pm 0.25$ in the maxilla, and 1.25 with $\mathrm{SD} \pm 0.35$ in the mandible, while after 4 weeks it was $2.84 \mathrm{~mm}$ with $\mathrm{SD} \pm 0.55$ in the maxilla, and 2.38 with $\mathrm{SD} \pm 0.18$ in the mandible and after 12 weeks it was $1.91 \mathrm{~mm}$ with $\mathrm{SD} \pm 0.27$ in the maxilla, and 1.63 with $\mathrm{SD} \pm 0.18$ in mandible.

in the mandible and after 12 weeks, it was $1.03 \mathrm{~mm}$ with $\mathrm{SD} \pm 0.09$ in the maxilla, and 1.00 with $\mathrm{SD} \pm 0.00$ in the mandible With non-significant $\mathrm{P}$-value between maxilla and mandible as shown in Table 4.

Table 1: Descriptive statistics of crestal bone measurements between flapped and flapless techniques at different time intervals

\begin{tabular}{|c|c|c|c|c|}
\hline Technique & Time intervals & Number & Mean & ISD \\
\hline \multirow{2}{*}{ Flapped } & $\mathbf{1}$ week & 10 & 1.28 & 0.25 \\
\hline & $\mathbf{4}$ weeks & 10 & 2.75 & 0.53 \\
\hline \multirow{2}{*}{ Flapless } & $\mathbf{1 2}$ weeks & 10 & 1.85 & 0.27 \\
\hline & $\mathbf{1 w e e k}$ & 10 & 1.35 & 0.21 \\
\hline
\end{tabular}

Table 2: Statistical analysis of crestal bone measurements between flapped and flapless techniques at different time intervals

\begin{tabular}{|c|c|c|}
\hline & Mann-Whitney U & 42.00 \\
\hline \multirow{2}{*}{1 week } & Wilcoxon W & 97.00 \\
& Z & -0.67 \\
\hline \multirow{2}{*}{4 weeks } & P-value & 0.50 \\
\hline & Mann-Whitney U & 3.00 \\
\hline & Wilcoxon W & 58.00 \\
\hline \multirow{2}{*}{12 weeks } & Z & -3.64 \\
\hline & P-value & 0.00 \\
\hline & Mann-Whitney U & 0.00 \\
\hline & Wilcoxon W & 55.00 \\
\hline
\end{tabular}




\section{Prosthodontics}

Table 3 Descriptive statistics of crestal bone measurements between flapped and flapless techniques in the maxilla and the mandible at different time intervals

\begin{tabular}{|c|c|c|c|c|c|}
\hline Technique & Time intervals & Jaw & $N$ & Mean & $\pm S D$ \\
\hline \multirow{6}{*}{$\begin{array}{l}\text { Flapped } \\
\text { (Control) }\end{array}$} & \multirow{2}{*}{1 week } & Maxilla & 5 & 1.28 & 0.25 \\
\hline & & Mandible & 5 & 1.25 & 0.35 \\
\hline & \multirow{2}{*}{4 weeks } & Maxilla & 5 & 2.84 & 0.55 \\
\hline & & Mandible & 5 & 2.38 & 0.18 \\
\hline & \multirow{2}{*}{12 weeks } & Maxilla & 5 & 1.91 & 0.27 \\
\hline & & Mandible & 5 & 1.63 & 0.18 \\
\hline \multirow{6}{*}{$\begin{array}{l}\text { Flapless } \\
\text { (Study) }\end{array}$} & \multirow{2}{*}{1 week } & Maxilla & 5 & 1.38 & 0.19 \\
\hline & & Mandible & 5 & 1.25 & 0.35 \\
\hline & \multirow{2}{*}{4 weeks } & Maxilla & 5 & 1.84 & 0.23 \\
\hline & & Mandible & 5 & 1.63 & 0.53 \\
\hline & \multirow{2}{*}{12 weeks } & Maxilla & 5 & 1.03 & 0.09 \\
\hline & & Mandible & 5 & 1.00 & 0.00 \\
\hline
\end{tabular}

Table 4 Statistics test of crestal bone measurements between flapped and flapless techniques in the maxilla and the mandible at different time intervals

Technique
Flapped
Flapless

\begin{tabular}{|c|}
\hline Statistics \\
\hline Mann-Whitney U \\
Wilcoxon W \\
Z \\
P-value \\
\hline Fisher exact test \\
Mann-Whitney U \\
Wilcoxon W \\
Z \\
P-value \\
Fisher exact test \\
\hline
\end{tabular}

\begin{tabular}{|c|}
\hline 1 week \\
\hline 7.500 \\
\hline 10.500 \\
\hline-0.144 \\
\hline 0.885 \\
\hline 0.889 \\
\hline 6.000 \\
\hline 9.000 \\
\hline-0.593 \\
\hline 0.553 \\
\hline 0.711 \\
\hline
\end{tabular}

\begin{tabular}{|c|}
\hline 4 weeks \\
\hline 4.000 \\
\hline 7.000 \\
\hline-1.067 \\
\hline 0.286 \\
\hline 0.400 \\
\hline 5.500 \\
\hline 8.500 \\
\hline-0.738 \\
\hline 0.460 \\
\hline 0.533 \\
\hline
\end{tabular}

\begin{tabular}{|c|}
\hline 12 weeks \\
\hline 3.000 \\
6.000 \\
\hline-1.412 \\
0.158 \\
\hline 0.267 \\
7.000 \\
\hline 10.000 \\
\hline-0.500 \\
\hline 0.617 \\
0.889 \\
\hline
\end{tabular}

\section{DISCUSSION}

Previous studies have revealed that flap reflection is the direct reason for bone resorption around natural teeth ${ }^{7}$. To reduce the possibility of postoperative periimplant tissue loss, the concept of the flapless implant surgery has been advocated for patients with sufficient available bone volume in the implant recipient site. The flapless technique is accepted as an alternative way for placing dental implants with less time and trauma ${ }^{15,16}$.

The present study null hypothesis assumed that the crestal bone level ase of the flapped dental implant surgery was significantly less compared with the flapless surgical technique, so from the results in table 1 and 2; the null hypothesis accepted since the flapless dental implant technique shows less level of bone resorption within time.

Comparison of the flapped and flapless techniques shows there were no significant differences at the $1^{\text {st }}$ weeks; this result is in agreement with Mijiritsky et al in 2011, who proved that there was no significant changes between the two techniques at 1 st weeks ${ }^{4}$, but when comparing the flapped and flapless techniques at the $4^{\text {th }}$ and $12^{\text {th }}$ weeks, there were significant differences between them. This study showed less crestal bone resorption using the flapless surgery was, which is in in agreement with Tsoukaki et al in 2013, who proved that there was greater crestal bone resorption at $6-12$ weeks using the flapped surgery and no bone resorption using the flapless technique ${ }^{17}$. Shibu et al in 2008 also proved low bone resorption using the flapless technique during 3 months post-surgical period ${ }^{18}$, while, Bayounis et al in 2011 proved better peri-implants healing using the flapless than that using the flapped technique ${ }^{19}$. The possible explanation is that the flapless surgery has also been reported to preserve the circulation of the peri-implant tissues and accelerate healing at the surgical site, thereby allowing the patient to resume regular oral hygiene maintenance immediately after 
implant placement ${ }^{20}$. In addition, the flapless surgical procedures are typically performed trans-mucosally without elevating the soft tissue covering the alveolar bone. The main benefit of this technique is the reduction in the level of trauma to the tissue, as the periosteum layer remains intact. Not disturbing the periosteum layer allows greater chance to preserve alveolar bone levels, improve blood supply to the implant site, and reduce patient discomfort ${ }^{20}$.

\section{CONCLUSION}

Within the limits of the present prospective study, placement of implants by the flapless approach has a potential to decrease crestal bone level loss, and minimize surgical time which is more comfortable to the patient.

\section{REFERENCES:}

1. Lemons JE, Laskin DM, Roberts WE,. Changes in patient screening for a clinical study of dental implants after increased awareness of tobacco use as a risk factor. Journal of Oral and Maxillofacial Surgery, 1997; 55(12 Supplement 5):S72-5.

2. Harris, D., Buser, D., Dula , K., Grondahl, K., Jabcobs, R., Lekholm, U., Nakielny, R., Vander Stelt, P.E.A.O.Guidelines for the Use of Diagnostic Imaging in Implant Dentistry. A Consensus Workshop Organized by the European Association for Ossteointegration in Trinty College Dublin. Clin Oral Implants Res,2002; 13(5):566-570.

3. Bashutski, J D, Wang, H, Rudek, I, et al. effects of flapless surgery on single tooth implant in esthetic zone : A Randomized Clinical Trial J Periodontology, Spain, 2013; vol 84(12). Pp.: 1747-1754.

4. Mijiritsky, E, Lorean, A, Barbu, H, et al .Full-Mouth Implant-supported Rehabilitation with a Flapless Surgical Technique: A Treatment Approach using ComputerAssisted Oral Implant Surgery. international journal of oral implantology, 2011;2(3):171-175.

5. Kohler, C.A. \& Ramfjord, S.P. Healing of gingival mucoperiostal flaps. Oral Surgery, Oral Medicine, and Oral Pathology 1960;13: 89-103.

6. Lobene, R. \& Glickman, I. The response of alveolar bone to grinding with rotary diamond stones. Journal of Periodontology 1963;34: 105-119.

7. Wood, D.I., Hoag, P.M., Donnenfeld, O.W. et al. Alveolar crest reduction following full and partial thickness flaps. Journal of Periodontology 1972; 43: 141-144.

8. Sklar AG: the bio-col technique. In: soft tissue and aesthetic consideration in implant therapy. Chicago, IL, Quintessence, 2003, p75.

9. Zoran V. Comparative radiographic and resonance radiographic analysis of peri-implants tissue after implant using flap and flapless technique. J Oral Maxillofac Radiology, 2013; vol 70 (6), pp. 586-594.

10. Choi, H B. Flapless Implantology, textbook, quintessence publishing, 2010.

11. Chrcanovic BR, Albrektsson T, Wennerberg A. Flapless versus conventional flapped dental implant surgery: a meta-analysis. PLoS One. 2014 Jun 20;9(6):e100624. doi:
10.1371 .

12. Ozan O, Turkyilmaz I, Yilmaz B. A preliminary report of patients treated with early loaded implants using computerized tomography-guided surgical stents: flapless versus conventional flapped surgery. J Oral Rehabil 2007; 34: 835-840.

13. Clark DE, Danforth RA, Barnes RW et al. Radiation absorbed from dental implant radiography: a comparison of linear tomography, CT scan, and panoramic and intraoral techniques, J Oral Implantol 1990; 3:156-164.

14. Olsson, J., Stearns, N., Tegration, O. Osseointegration of Immediately Loaded Dentall Implants in the Edntulous Jaws. A study of the literature institute of odontology, Karolinskainstatute 2004 :287-299.

15. Campelo LD, Camara JR. Flapless implant surgery: a 10year clinical retrospective analysis. Int J Oral Maxillofac Implants. 2002;17:271-276.

16. Rocci A, Martignoni M, Gottlow J. Immediate loading in the maxilla using flapless surgery, implants placed in predetermined positions, and prefabricated provisional restorations: a retrospective 3-year clinical study. Clin Implant Dent Relat Res. 2003;5(Suppl.):29-36.

17. Tsoukaki M, Kalpidis CD, Sakellari D, et al: clinical radiograph, microbiological, and immunological outcome of flapped vs flapless dental implant. Clinical oral implants research 2013; 24(9): 969-76.

18. Shibu J., Vinaya B., Naidu E. in vivo evaluation of crestal bone height following implant placement with flapp and flapless technique in site of immediately loaded implants. Indian J. Dent. Research. 2008; Vol(19) iss(4) pp.320-325..

19. Bayounis AM, Alzoman HA, Jansen JA et al. healing of peri-implants tissues after flapless and flapped implants installation. J. clinin perio. 2011; vol(38), iss (8), pp.754761.

20. Sunitha RV, Sapthagiri E. Flapless implant surgery: A 2-year follow-up study of 40 implants. Oral Surg Oral Med Oral Pathol Oral Radiol 2013;116:e237-e243. 